\title{
Ústava SR - pojem, vznik, štruktúra a novelizácia
}

Jaroslav Chovanec*

DOI: https://doi.org/10.24040/sap.2021.8.2-3.134-146

\begin{abstract}
Abstrakt:
CHOVANEC, Jaroslav: Ústava Slovenskej republiky - pojem, vznik, štruktúra a novelizácia. Autor v štúdii definuje pojem ústavy, rozoberá a hodnotí vznik Ústavy Slovenskej republiky, jej štruktúru, ako aj novelizáciu. Pritom poukazuje, že Ústava Slovenskej republiky bola od svojho vzniku a účinnosti (1. september 1992 a 1. október 1992 a 1. január 1993) dvadsatkrát novelizovaná. Taktiež upozorňuje, že tretia tzv. vel'ká novela ústavy (ústavný zákon č. 90/2001 Z. z.) a posledná novela ústavy (ústavný zákon č. 422/202 Z. z.) boli najrozsiahlejšie oproti ostatným novelám Ústavy Slovenskej republiky. V štúdii autor v stručnosti zhodnotil i najdôležitejšie ústavné inštitúcie a inštitúty. Ďalej okrem iného poukazuje i na kritiku najmä poslednej novely Ústavy Slovenskej republiky, a to so zdôraznením, že ju kritizuje vel'ká skupina sudcov a prokurátorov, ako aj súčasná opozícia. Taktiež poukazuje na skutočnost', že poslednú novelu Ústavy Slovenskej republiky kritizuje i odborná vedecká a právnická komunita. Záverom štúdie autor zdôrazňuje, že Ústava Slovenskej republiky vytvorila ústavnoprávne podmienky pre budovanie demokratického právneho štátu, ako aj pre vstup Slovenskej republiky do euroatlantických štruktúr, t. j. do NATO a Európskej únie a taktiež pre mierovú spoluprácu Slovenskej republiky so štátmi sveta. Pritom ešte autor upozorňuje na významnú skutočnost', že Ústava Slovenskej republiky je porovnatel'ná s ústavami najmä štátov Európskej únie.
\end{abstract}

\section{Kl’účové slová:}

ústava, ústavný zákon, zákon, novelizácia, zákonodarná moc, výkonná moc, súdna moc

\section{Constitution of the Slovak Republic - Concept, Origin, Structure and Amendment}

\begin{abstract}
:
CHOVANEC, Jaroslav: Constitution of the Slovak Republic - concept, origin, structure and amendment. In the study, the author defines the concept of the constitution, analyzes and evaluates the origin of the Constitution of the Slovak Republic, its structure, as well as the amendment. At the same time, it points out that the Constitution of the Slovak Republic has been amended twenty times since its inception and effect (1 September 1992 and 1 October 1992 and 1 January 1993). He also points out that the third so-called The major amendment to the Constitution (Constitutional Act No. 90/2001 Coll.) and the last amendment to the Constitution (Constitutional Act No. 422/202 Coll.) were the most extensive compared to other amendments to the Constitution of the Slovak
\end{abstract}

\footnotetext{
Dr. h. c. prof. JUDr. Jaroslav Chovanec, CSc. Katedra právnych a humanitných vied, Fakulta masmediálnej komunikácie UCM v Trnave.
} 


\begin{abstract}
Republic. In the study, the author briefly evaluated the most important constitutional institutions and institutes. He also points out, among other things, the criticism of the latest amendment to the Constitution of the Slovak Republic, emphasizing that it is criticized by a large group of judges and prosecutors, as well as the current opposition. He also points out the fact that the latest amendment to the Constitution of the Slovak Republic is also criticized by the professional scientific and legal community. At the end of the study, the author emphasizes that the Constitution of the Slovak Republic created the constitutional conditions for building a democratic rule of law, as well as for the entry of the Slovak Republic into Euro-Atlantic structures, i. j. to NATO and the European Union and also for the peaceful cooperation of the Slovak Republic with the countries of the world. At the same time, the author also draws attention to the important fact that the Constitution of the Slovak Republic is comparable to the constitutions of the states of the European Union in particular.
\end{abstract}

\title{
Keywords:
}

constitution, constitutional law, law, amendment, legislative power, executive power, judicial power

\section{Úvod}

Ústava ako všeobecný pojem je definovaná takto: je to základný zákon štátu majúci najvyššiu právnu silu, osobitne predpísanú formu prijatia a komplexný obsah upravujúci najdôležitejšie spoločenské vzt’ahy vrátane štruktúry, štátnych, súdnych a samosprávnych orgánov a orgánov ochrany ústavnosti a ich vzájomných vzt'ahov, taktiež základných práv a slobôd občanov, ako právny a politický dokument vytvára ústavnoprávnu základňu pre legislatívnu činnost' a tvorbu d'alších právnych noriem ako i pre inštitucionálne a demokratické riadenie štátu a spoločnosti. ${ }^{1}$

Ústava Slovenskej republiky bola schválená 1. septembra 1992 Slovenskou národnou radou a podpísaná predsedom Slovenskej národnej rady a predsedom vlády SR dňa 3. septembra 1992 na Bratislavskom hrade. Nadobudla účinnost' dňom vyhlásenia 1. októbra 1992, (ked' bola vyhlásená v Zbierke zákonov Slovenskej republiky), okrem niektorých článkov priamo citovaných v čl. 156 ústavy. V plnom rozsahu nadobudla účinnost' 1. januára 1993, ked' ňou a v súčinnosti s ústavným zákonom FZ ČSFR č. 542/1992 Zb. o zániku Českej a Slovenskej Federatívnej republiky sa konštituovala Slovenská republika ako samostatný, suverénny a nezávislý demokratický šát.

Z hl'adiska štruktúry sa Ústava Slovenskej republiky skladá z dvoch častí - preambuly a deviatich hláv, ktoré tvoria druhú čast' rozdelenú na jednotlivé oddiely a celkove 156 článkov. Štruktúra Ústavy SR je nasledujúca: Preambula, Základné ustanovenia (prvá hlava čl. 1-10), Základné práva a slobody (druhá hlava čl. 11-54), Hospodárstvo Slovenskej republiky a Najvyšší kontrolný úrad Slovenskej republiky (tretia hlava čl. 55-63), Územná samospráva (štvrtá hlava čl. 64-71), Zákonodarná moc (piata hlava čl. 72-100), Výkonná moc (šiesta hlava čl. 101-123), Súdna moc (siedma hlava čl. 124-148), Prokuratúra Slovenskej republiky (ôsma hlava čl. 149151), Prechodné a záverečné ustanovenia (deviata hlava čl. 152-156).

1 CHOVANEC, J. - PALÚŠ, J. Lexikón ústavného práva. Bratislava : Procom, 2004, s. 133-134. 
V ústavnom práve SR, a taktiež v štátovede je venovaný pomerne vel'ký priestor polemike a hodnoteniu preambúl jednotlivých ústav, ktoré boli prijaté na území Česko-Slovenska a Slovenska, a osobitne v Preambule Ústavy SR (z. 1. septembra 1992) platnej a účinnej v novelizovanom znení v súčasnosti. Pritom sa žiada upozornit' na skutočnost', že pri jej hodnotení sa vyskytujú rôzne názory. ${ }^{2}$

Prijatím Ústavy SR 1. septembra 1992 Slovenskou národnou radou bol ukončený emancipačný proces slovenského národa za samostatný, suverénny a nezávislý slovenský štát - Slovenská republika. V tejto súvislosti sa žiada poukázat' na významnú skutočnost', že pri celkovom hodnotení pôvodného textu Ústavy SR, jej princípov, obsahu a formy zakotvených inštitútov a inštitúcí́ treba zdôraznit' jej nezastupitelný význam pre budovanie slovenskej spoločnosti. Ústava SR sa stala základom budovania právneho a demokratického štátu, ako aj základom budovania politického systému a právneho poriadku Slovenskej republiky. Vytvorila i ústavnoprávny základ na možnost' vstupu Slovenskej republiky do medzinárodných európsko - atlantických štruktúr, do Rady Európy a mnohých medzinárodných organizácií a postupne i vstup do Európskej únie. Taktiež treba osobitne zdôraznit', že Ústava SR je porovnatel'ná s ktoroukolvvek ústavou vyspelých štátov Európy. ${ }^{3}$

Kladné hodnotenie Ústavy Slovenskej republiky potvrdzuje i stanovisko parlamentného zhromaždenia Rady Európy z obdobia prijímania SR do Rady Európy z 11. júna 1993, v ktorom sa okrem iného hovorí: „Nová ústava, ktorá vstúpila do platnosti 1. januára 1993,, utvára zo Slovenskej republiky štát, ktorý uznáva vládu zákona a zaručuje l’udské práva a základné slobody.“4

Na margo ústavy sa taktiež kladne vyjadril i významný právnik, sudca Európskeho súdu pre l'udské práva prof. Pettiti, ktorý v súvislosti so vstupom Slovenskej republiky do Rady Európy povedal: „Vaša ústava je naozaj dobrá, mal som úlohu naštudovat' a posúdit’ ju pred prijatím Slovenskej republiky do Rady Európy. “5

Ďalej môžeme uviest' vysoko pozitívne hodnotenie Ústavy Slovenskej republiky, ktoré vyjadril prezident Európskej komisie pre l’udské práva prof. Stefan Treschel,

2 Priestor tohto článku nám neumožňuje ich rozoberat' a hodnotit'. Vzhl’adom na túto skutočnost' sme do článku zaradili konkrétny obsah Preambuly súčasne platnej Ústavy Slovenskej republiky. Preambula platnej Ústavy Slovenskej republiky znie takto: „My, národ slovenský, pamätajúc na politické a kultúrne dedičstvo svojich predkov a na stáročné skúsenosti zo zápasov o národné bytie a vlastnú štátnost', v zmysle cyrilo-metodského duchovného dedičstva a historického odkazu Vel'kej Moravy, vychádzajúc z prirodzeného práva národov na sebaurčenie, spoločne s príslušníkmi národnostných menšín a etnických skupín žijúcich na území Slovenskej republiky, $v$ záujme trvalej mierovej spolupráce s ostatnými demokratickými štátmi, usilujúc sa o uplatňovanie demokratickej formy vlády, záruk slobodného života, rozvoja duchovnej kultúry a hospodárskej prosperity, teda my, občania Slovenskej republiky, uznášame sa prostredníctvom svojich zástupcov na tejto ústave: ..." Ústava Slovenskej republiky č.460/1992 Zb. Bližšie k otázkam preambuly našej ústavy pozri napr.: GIBA, M. Ústavné právo. Bratislava : UK, 2019, s. 68. GIBA, M. Potrebuje slovenská ústava zmenu? In : Ústava Slovenskej republiky 20 rokov v národnom a európskom pohlade. Lutila : Lonfinger, 2012, s.193-209.

3 CHOVANEC, J. Ústava SR - základný zákon štátu. Bratislava : Procom, 2002, s.114.

4 Parlamentary Assembly, assemble parlamentaire, 11 june 1993, ADOC 6864, 1483-9/6/93 - 1 -E. doc. 6864, s.1.

5 ČIČ, M.: Živé slová. Slovenský rozhlas Bratislava, marec 1996, s. 3. 
ktorý sa zúčastnil na slávnostnom zhromaždení Matice slovenskej v Diviakoch pri príležitosti piateho výročia Ústavy Slovenskej republiky a ktorý okrem iného na margo Ústavy Slovenskej republiky povedal: „Ústava Slovenskej republiky spíňa všetky predpoklady demokratickej ústavy a má všetky princípy demokratických a humanistických zásad.“"

Štátoveda v rámci historického vývoja ústavy a teórie ústavy delí ústavy na: písané, nepísané, tuhé, pružné, právne, praktické, revolučné, živé, prenosné, oktrojované, reálne a fiktívne. ${ }^{7} \mathrm{~V}$ tejto súvislosti môžeme Ústavu SR charakterizovat' ako písanú, tuhú, ústavu právnu a živú a dohodnutú a reálnu. Taktiež môžeme upozornit' na skutočnost', že ústavy majú i svoje funkcie. Ide najmä o tieto funkcie ústav: právna, stabilizačná, dynamická, integračná, politická, ideologická a kultúrna funkcia ústavy. ${ }^{8}$

\section{Novelizácie Ústavy SR}

Ústava Slovenskej republiky od plnej účinnosti t. j. od 1. januára 1992 bola dvadsat' krát novelizovaná. Ide o tieto ústavné zákony, ktorými sa Ústava SR menila, resp. novelizovala:

- Prvá novela sa uskutočnila ústavným zákonom č. 244/1998 Z. z. (úst. Zákon č. 244/1998 Z. z.) zakotvovala, že prezidenta SR volí NR SR na návrh najmenej ôsmich poslancov tajným hlasovaním na pät' rokov. V druhom ustanovení táto novela zakotvovala, že ak je uvol’nený úrad prezidenta SR, sa niektoré jeho právomoci presunú na predsedu NR SR. Išlo o tieto právomoci: právomoc vymenovat' a odvolávat' predsedu a ostatných členov vlády SR, právo vymenovat' a odvolávat' predsedu a ostatných členov vlády SR, právo vymenovat' a odvolávat' vedúcich ústredných orgánov a vyšších štátnych funkcionárov ustanovených zákonom, ako aj právo vymenúvat' profesorov a rektorov vysokých škôl a vymenúvat' a povyšovat' generálov.

- Druhá novela (úst. zákon č. 9/1999 Z. z.) zaviedla priamu vol'bu prezidenta SR na pät' rokov občanmi a taktiež zaviedla právo odvolat' prezidenta pred ukončením volebného obdobia l'udovým hlasovaním. Okrem týchto dvoch hlavných zmien sa predmetná novela Ústavy SR dotýkala i právomoci predsedu NR SR, prezidenta SR a Ústavného súdu SR, ako i procesu vol'by prezidenta SR

- Tretia, tzv. Vel'ká novela Ústavy SR bola prijatá vo februári 2001, a to pod č. ústavného zákona 90/2001 Z. z., a nadobudla účinnost' 1. júla 2001 (okrem niektorých ustanovení). Vel'ká novela Ústavy SR sa okrem preambuly Ústavy SR dotýka vlastne zmeny všetkých hláv Ústavy SR. Vzhl'adom na skutočnost', že do textu Ústavy SR boli zapracované všetky tri novely Ústavy a následne bola táto publikovaná ako „úpl-

6 Slovenské národné noviny, č. 38/1997, s.7.

7 Bližšie pozri: POSLUCH, M. - CIBULKA, L. Štátne právo Slovenskej republiky, 3. vydanie. Šamorín : Heuréka, 2009, s.46-48.

8 Tamže, s.49-55 a taktiež: PALÚŠ, J. a kol. Ústavné právo Slovenskej republiky. Košice : Fakulta verejnej správy UPJŠ, s. 58-70. Porovnaj s HOLLANDER, P. Základy všeobecné státovédy. Praha : Vyšehrad, 1995; HOLLANDER, P. Základy obecné státovědy. 3 vydání. Plzeň : Aleš Čeněk, 2012; KLÍMA, K. Státověda. 2 vydání. Plzeň : Aleš Čeněk, 2011; PROCHÁZKA, R. - KÁČER, M. Teória práva. 1. Vyd. Bratislava: C. H. Beck, 2013; FÁBRY, B. - KASINEC, R. - TURČAN, M. Teória práva. Bratislava: Wolters Kluwer 2017; PAVLÍČEK, V. a kol. Ústavní právo a státověda. I. díl - Obecná státověda. 2015. 
né znenie Ústavy SR“ pod č. 135/2001 Z. z., jednotlivé zásahy do pôvodného textu Ústavy SR neuvádzame a nerozoberáme. ${ }^{9}$

- Ústavným zákonom č. 140/2004 Z. z. a ústavným zákonom č. 323/2004 Z. z., ktoré v článku 78 ods. 2 sa vypúšt’a tretia veta a v článku 77 ods. 1 sa pripájajú slová „... a poslanca Európskeho parlamentu“. Ďalej v článku 129 ods. 2 sa pridáva text: „... a volieb do Európskeho parlamentu“".

- Ústavný zákon č. 323/2004 Z. z. zmenil text Ústavy SR nasledovne: v čl. 129 odsek 2 znie: „(2) ústavný súd rozhoduje o ústavnosti a zákonnosti volieb prezidenta Slovenskej republiky, volieb do Národnej rady SR, volieb do orgánov územnej samosprávy a volieb do Európskeho parlamentu".

- Ústavným zákonom č. 463/2005 Z. z. sa rozširuje právomoc Najvyššieho kontrolného úradu Slovenskej republiky, a to v článku 60 ods. 1 a ods. 2 Ústavy SR. Tak tiež mení článok 103 ods. 4 d’alej doterajší text článok 126 sa označuje ako odsek 1 a dopĺn̆a odsekom 2, ktorý znie: ,ústavný súd rozhoduje v sporných prípadoch o tom, či je daná kontrolná pôsobnost' Najvyššieho kontrolného úradu Slovenskej republiky.“

- Ústavným zákonom č. 92/2006 Z. z. sa menia právomoci Verejného ochrancu práv Slovenskej republiky, a to v článkoch 130 ods. 1 a článku 151 a ods. 1 - do tohto článku sa vkladá i ods. 2. ktorý znie: „Verejný ochranca práv sa môže podielat’ na uplatneni zodpovednosti osôb pôsobiacich v orgánoch verejnej moci, ak tieto osoby porušili základné právo alebo slobodu fyzických osôb a právnických osôb. Všetky orgány verejnej moci poskytnú verejnému ochrancovi práv potrebnú činnost."“

- Ústavným zákonom č. 210/2006 Z. z. sa mení článok 78 ods. 3 v prvej vete sa na konci bodka nahrádza bodkočiarkou a pripájajú sa tieto slová: „možno však prejednat priestupok, o ktorom to ustanoví zákon “. Toto ustanovenie sa dotýka vlastne priestupkovej imunity poslancov NR SR. Dôvodová správa k predmetnému ústavnému zákonu vo všeobecnej časti okrem iného hovorí: „Predloženým návrhom, ústavného zákona sa v súvislosti s uvedeným výkladom (v dôvodovej správe) navrhuje zúzit' poslaneckú imunitu za priestupky prostrednictvom zákona, ktorý sa vydá na základe navrhovanej zmeny článku 78 ods. 3 ústavy. Najvhodnejším spôsobom konkrétneho zúženia poslaneckej imunity za priestupky bude zmena zákona č.372/1990 Zb. o priestupkoch, na ktoré sa imunita nebude vzt'ahovat'." Priestupková imunita poslancov NR SR bola zrušená zákonom NR SR č. 79/2012 Z. z. 1. marca 2012.

- Ústavným zákonom č. 100/2010 Z. z. zo 4 marca 2010, ktorý nadobudol účinnost' 1. januára 2011, sa doplńa, resp. vkladá v článku 20 ods. 41 za druhú vetu tretia veta, ktorá znie: „Majetok nadobudnutý v rozpore s právnym poriadkom ochrana nepouživa.“ Ďalej sa článok 20 dopíňa odsekom 5, a to takto: „Iné zásahy do vlastníckeho práva možno dovolit' iba vtedy, ak ide o majetok nadobudnutý nezákonným spôsobom alebo z nelegálnych prijímov a ide o opatrenie nevyhnutné v demokratickej spoločnosti pre bezpečnost'š tátu, ochranu verejného poriadku, mravnosti alebo práv a slobôd iných."

- Ústavným zákonom č. 356/2011 Z. z. z 21. októbra 2011 sa Ústava SR doplńa takto: 1 . v čl. 102 sa odsek 1 dopíña písmenom u), ktoré znie: „rozhoduje o povereni

9 Bližšie o týchto troch novelách pozri: CHOVANEC, J. - PALÚŠ, J. Lexikon ústavného práva. Bratislava : Procom, 2004, s.144-154 a CHOVANEC, J. Ústava SR základný zákon štátu. Bratislava : Procom 2002, s.125-140. 
vlády a dáva súhlas na výkon jej pôsobnosti podla čl. 115 ods.3.“2. čl. 115 sa dopín̆a odsekom 3, ktorý znie: „Ak prezident Slovenskej republiky odvolá vládu podla odseku 1, rozhodnutím, vyhláseným v Zbierke zákonov Slovenskej republiky, ju poverí vykonávaním jej pôsobnosti až do vymenovania novej vlády, avšak výlučne v rozsahu podla čl. 119 písm. a), b), e), f), m), n) o), p), a r), výkon pôsobnosti vlády podla čl. 119 pism. m) a r) je v každom jednotlivom prípade viazaný na predchádzajúci súhlas prezidenta Slovenskej republiky."

- Ústavný zákon č. 232/2012 Z. z., zmenil text Ústavy SR nasledovne: $1 . V$ čl. 78 odsek 3 znie: „Poslanca nemožno vziat do väzby bez súhlasu Národnej rady Slovenskej republiky“. 2. V čl. 78 odsek 4 znie: ,ak bol poslanec pristihnutý a zadržaný pri trestnom čine, príslušný orgán je povinný to ihned' oznámit' predsedovi Národnej rady SR a predsedovi mandátového výboru Národnej rady SR. Ak mandátový výbor Národnej rady SR, následný súhlas na zadržanie nedá, poslanec musí byt' ihned' prepusteny"“. 3.V čl. 131. ods. 1 slová ,„čl. 136 ods. 2 a 3“" nahrádzajú slovami - ,čll. 136 ods. 1 a 2.“ 4.V čl. 136 sa vypúšt’a odsek 1 . doterajší odsek 2 až 4 sa označuje ako odsek 1 až 3.

- Ústavným zákonom č. 161/2014 Z. z. zo 4. júna 2014 sa zmenil text Ústavy SR nasledovne: V Čl. I. Ústava SR sa mení a dopĺn̆a takto:1. V čl. 41 odsek 1 znie: „Manželstvo je jedinečný zväzok medzi mužom a ženou. Slovenská republika manželstvo všestranne chráni a napomáha jeho dobru. Manželstvo, rodičovstvo a rodina sú pod ochranou zákona. Zaručuje sa osobitná ochrana detí a mladistvých." 2. V čl. 129 sa za odsek 6 vkladá nový odsek 7, ktorý znie: ,Ústavný súd rozhoduje o stažnosti proti uzneseniu Súdnej rady Slovenskej republiky podl’a čl. 154d ods. 2. “ 3. V čl. 130 ods. 1 sa za písmeno e) vkladá nové písmeno f), ktoré znie: ,predseda Súdnej rady Slovenskej republiky vo veciach súladu právnych predpisov podla čl. 125 ods. 1 týkajúcich sa výkonu súdnictva,“. 4. V čl. 131 ods. 1 sa slová ,, čl. 129 ods. 2 až 6 " nahrádzajú slovami „čl. 129 ods. 2 až 7 “ a slová „,̌l. 136 ods. 1 a 2 “ sa nahrádzajú slovami „čl. 136 ods. 2 a 3“. 5. Čl. 133 znie: „Proti rozhodnutiu ústavného súdu nemožno podat' opravný prostriedok; to neplatí, ak rozhodnutím orgánu medzinárodnej organizácie zriadeného na uplatňovanie medzinárodnej zmluvy, ktorou je Slovenská republika viazaná, vznikne Slovenskej republike povinnost'v konani pred ústavným súdom znovu preskúmat' už prijaté rozhodnutie ústavného súdu.“ 6. Článok 136 znie: „, (1) Za rozhodovanie pri výkone funkcie nemožno sudcu ústavného súdu trestne stíhat', a to ani po zániku jeho funkcie. (2) Ak bol sudca ústavného súdu pristihnutý a zadržaný pri páchaní trestného činu, príslušný orgán je povinný to ihned' oznámit' predsedovi ústavného súdu, a ak ide o predsedu ústavného súdu, podpredsedovi ústavného súdu. Sudcu ústavného súdu nemožno vziat do väzby bez súhlasu ústavného súdu. (3) Ústavný súd dáva súhlas na vzatie do väzby sudcu a generálneho prokurátora. Ústavný súd vykonáva disciplinárne konanie voči predsedovi Najvyššieho súdu Slovenskej republiky, podpredsedovi Najvy̌̌šieho súdu Slovenskej republiky a generálnemu prokurátorovi.“”

- Ústavným zákonom č. 306/2014 Z. z. z 21. októbra 2014, sa zmenil text Ústavy SR nasledovne: V čl. 4 sa na konci pripája táto veta: „Slovenská republika chráni a zvelad'uje toto bohatstvo, šetrne a efektivne využiva nerastné bohatstvo a prírodné dedičstvo v prospech svojich občanov a nasledujúcich generácií." 2. Doterajší text čl. 4 sa označuje ako odsek 1 a doplńa sa odsekom 2, ktorý znie:, Preprava vody odobratej z vodných útvarov nachádzajúcich sa na území Slovenskej republiky cez 
hranice Slovenskej republiky dopravnými prostriedkami alebo potrubím sa zakazuje; zákaz sa nevztahuje na vodu na osobnú spotrebu, pitnú vodu balenú do spotrebitel'ských obalov na územi Slovenskej republiky a prirodnú minerálnu vodu balenú do spotrebitel'ských obalov na území Slovenskej republiky a na poskytnutie humanitárnej pomoci a pomoci v núdzových stavoch. Podrobnosti o podmienkach prepravy vody na osobnú spotrebu a vody na poskytnutie humanitárnej pomoci a pomoci v núdzových stavoch ustanoví zákon."

- Ústavným zákonom č. 427/2015 Z. z. z 8. decembra 2015, sa zmenil text Ústavy SR nasledovne: V čl. 17 ods. 3 druhá veta znie: „Zadržaná osoba musí byt' ihned oboznámená s dôvodmi zadržania, vypočutá a najskôr do 48 hodín a pri trestných činoch terorizmu do 96 hodín prepustená na slobodu alebo odovzdaná súdu."

- Ústavným zákonom č. 44/2017 Z. z. z 2. februára 2017, sa zmenil text Ústavy SR nasledovne: Za čl. 154d sa vkladá čl. 154e, ktorý znie:,, (1) Poslancov zastupitelstiev vyššich územných celkov a predsedov vyššich územných celkov volia vo vol'bách v roku 2017 obyvatelia, ktorí majú trvalý pobyt v územnom obvode vy̌šsieho územného celku, na základe všeobecného, rovného a priameho volebného práva tajným hlasovaním na pätročné obdobie. (2) Ustanovenia čl. 69 ods. 5 druhej vety a ods. 6 prvej vety sa pre volebné obdobie poslancov zastupitel'stiev vyššich územných celkov a predsedov vyšších územných celkov pre volebné obdobie začínajúce v roku 2017 nepoužijú.“

- Ústavným zákonom č. 71/22017 Z. z. z 30. marca 2017, sa zmenil text Ústavy SR nasledovne:1. V čl. 84 odsek 4 znie: „Na prijatie ústavy, zmenu ústavy, ústavného zákona, na vyslovenie súhlasu s medzinárodnou zmluvou podl’a čl. 7 ods. 2, na prijatie uznesenia o l'udovom hlasovani o odvolani prezidenta Slovenskej republiky, na podanie obžaloby na prezidenta, na vypovedanie vojny inému štátu a na zrušenie rozhodnutia prezidenta podl'a čl. 102 ods. 1 pism.j) je potrebný súhlas aspon̆ trojpätinovej väčšiny všetkých poslancov. “2. V čl. 86 sa za písmeno h) vkladá nové písmeno i), ktoré znie: „uznášat' sa o zrušení rozhodnutia prezidenta podla čl. 102 ods. 1 písm. j), ak odporuje princípom demokratického a právneho štátu; prijaté uznesenie je všeobecne záväzné a vyhlasuje sa rovnako ako zákon.“ 3. Za čl. 88 sa vkladá čl. 88a, ktorý znie: „Návrh na zrušenie rozhodnutia prezidenta podl'a čl. 102 ods. 1 písm. j) prerokuje Národná rada Slovenskej republiky vtedy, ked’o to požiada najmenej pätina jej poslancov.“ 4. Za čl. 129 sa vkladá čl. 129a, ktorý znie: „Ústavný súd rozhoduje o súlade uznesenia Národnej rady Slovenskej republiky o zrušení amnestie alebo individuálnej milosti prijatého podl'a čl. 86 písm. i) s Ústavou Slovenskej republiky. Ústavný súd začne konanie vo veci podl'a prvej vety bez návrhu; čl. 125 sa použije primerane. “ $5 . \mathrm{V}$ čl. 131 odsek 1 znie: „Ústavný súd rozhoduje v pléne vo veciach uvedených v čl. 105 ods. 2, čl. 107, čl. 125 ods. 1 pism. a) a b), čl. 125 a ods. 1, čl. $125 b$ ods. 1, čl. 128, čl. 129 ods. 2 až 7, čl. 129a, čl. 136 ods. 2 a 3, čl. 138 ods. 2 písm. b) a c), o zjednocovaní právnych názorov senátov, o úprave svojich vnútorných pomerov a o návrhu rozpočtu ústavného súdu. Plénum ústavného súdu sa uznáša nadpolovičnou väčsinou všetkých sudcov. Ak sa táto väčšina nedosiahne, návrh sa zamietne. Ak sa ústavnýs súd vo veci podl'a čl. 129 a neuznesie nadpolovičnou väčšinou všetkých sudcov, konanie sa zastavi. “ 6 . Za čl. 154e sa vkladá čl. 154f, ktorý znie: „(1) Ustanovenia čl. 86 pism. i), čl. 88 a a čl. 129 a sa vzt’ahujú aj na článok V a článok VI rozhodnutia predsedu vlády Slovenskej republiky z 3. marca 1998 o amnestii uverejneného pod 
čislom 55/1998 Z. z., rozhodnutie predsedu vlády Slovenskej republiky zo 7. júla 1998 o amnestii uverejnené pod č́slom 214/1998 Z. z. a rozhodnutie prezidenta Slovenskej republiky v konani o milost' pre obvineného zo dña 12. decembra 1997 č. $k$. 3573/9672-2417. (2) Zrušením amnestií a milostí podl'a odseku 1 a) sa zrušujú rozhodnutia štátnych orgánov v rozsahu, v ktorom boli vydané a odôvodnené na základe amnestií a milostí uvedených vodseku 1 a b) zanikajú zákonné prekážky trestných stíhani, ktoré mali základ $v$ amnestiách a milostiach uvedených v odseku 1; doba trvania týchto zákonných prekážok sa nezapočitava do premlčacích dôb vztahujúcich sa na skutky, ktorých sa amnestie a milosti uvedené v odseku 1 týkajú.“

- Ústavným zákonom č. 137/2017 Z. z. zo 16. mája 2017 sa zmenil text Ústavy SR nasledovne: Čl. I. sa mení a dopíňa takto: „1. V čl. 20 ods. 2 sa v prvej vete za slová ,zabezpečovanie potrieb spoločnosti, “vkladajú slová ,potravinovej bezpečnosti štátu, “ a slová „obce alebo určených právnických osôb" sa nahrádzajú slovami „obce, určených právnických osôb alebo určených fyzických osôb. “2. V̌̌ll. 44 ods. 4 sa za slová ,využivanie prírodných zdrojov, “ vkladajú slová „o ochranu polnohospodárskej pôdy a lesnej pôdy, " $3 . V$ čl. 44 sa za odsek 4 vkladá nový odsek 5, ktorý znie:,,(5) Polnohospodárska pôda a lesná pôda ako neobnovitelné prírodné zdroje poživajú osobitnú ochranu zo strany štátu a spoločnosti. " Doterajši odsek 5 sa označuje ako odsek 6.4. Včl. 44 ods. 6 sa slová ,odsekov 1 až 4 “ nahrádzajú slovami „odsekov 1 až $5 “$ “.

- Ústavným zákonom č. č. 99/2019 Z. z. z 28. marca 2019, sa zmenil text Ústavy SR nasledovne: 1. Doterajší text čl. 36 sa označuje ako odsek 1 a dopíňa sa odsekom 2, ktorý znie:,Každý zamestnanec má právo, aby jeho odmena za vykonanú prácu nebola nižšia ako minimálna mzda. Podrobnosti o úprave minimálnej mzdy ustanovi zákon.“ 2. V čl. 39 sa za odsek 1 vkladajú nové odseky 2 a 3, ktoré znejú: „(2) Primerané hmotné zabezpečenie $v$ starobe sa vykonáva prostredníctvom priebežne financovaného dôchodkového systému a systému starobného dôchodkového sporenia. Štát podporuje dobrovolné sporenie na dôchodok.(3) Vek potrebný na vznik nároku na primerané hmotné zabezpečenie $v$ starobe nesmie presiahnut' 64 rokov. Žena má právo na primerané zniženie maximálneho veku potrebného na vznik nároku na primerané hmotné zabezpečenie $v$ starobe o a) šest' mesiacov, ak vychovala jedno diet'a, b) dvanást' mesiacov, ak vychovala dve deti, c) osemnást' mesiacov, ak vychovala tri a viac deti."

V súvislosti s novelizáciou Ústavy Slovenskej republiky sa žiada poukázat' na skutočnost', že dňa 13. októbra 2011 bol prijatý Národnou radou SR ústavný zákon č. 330/2011 Z. z. o skrátení volebného obdobia Národnej rady SR. Národná rada SR sa uzniesla na tomto ústavnom zákone:,,(1) Volebné obdobie Národnej rady SR zvolenej v roku 2010 sa uskutočni dňom volieb do Národnej rady Slovenskej republiky.(2) Vol'by do Národnej rady SR sa uskutočnia 10. marca 2012. Na tomto mieste sa žiada upozornit' na skutočnost', že ústavný zákon č. 330/2011 Z. z. o skrátení volebného obdobia Národnej rady SR nemenil Ústavu Slovenskej republiky. Bol prijatý Národnou radou SR na ,jedno použitie“.

Všetky novely Ústavy SR sú samostatne publikované v Zbierke zákonov. Redakčné úpravy sú zapracované do platného znenia Ústavy Slovenskej republiky na 
internete v programe ASPI. Na záver treba konštatovat', že Ústava Slovenskej republiky je základným ústavnoprávnym a politickým aktom zavŕšenia národnoemancipačných snáh a naplnením historických túžob slovenského národa po vlastnom štáte. Je základom vzniku slovenskej štátnosti vo forme samostatnej, suverénnej a nezávislej Slovenskej republiky. Všetky uskutočnené novely Ústavy SR platia a majú svoju účinnost', a preto ich treba s plnou dôslednost'ou uplatňovat' v ústavnoprávnej a spoločensko-politickej praxi na prospech našich občanov a budovania Slovenskej republiky ako moderného štátu európskeho typu.

Nález Ústavného súdu Slovenskej republiky č. 40/2019 Z. z., sp. zn. PL ÚS 21/2014 z 30. januára 2019 novelizoval Ústavu Slovenskej republiky, a to tak, že poukázal na niektoré ustanovenia, ktorými bola Ústava SR novelizovaná v roku 2014. Pritom poukázal aj na súvislosti s právnou úpravou overovania sudcovskej spôsobilosti Národným bezpečnostným úradom, a to, že ,nie sú $v$ súlade s príslušnými ustanoveniami Ústavy SR.“ Tiež nález Ústavného súdu SR nevyhovel návrhu predsedníčky Súdnej rady SR o zmene a doplnení niektorých zákonov v znení neskorších predpisov, o ochrane utajovaných skutočností a o zmenu a doplnenie niektorých zákonov v znení neskorších predpisov, že nie sú v súlade s príslušnými ustanoveniami Ústavy SR (teda s. čl. 1 ods. 1 , čl. 141 ods. 1 a čl. 144 ods. 1 Ústavy SR). V tejto súvislosti sa žiada upozornit' na skutočnost', že ak Národná rada SR nedá príslušné ustanovenia do súladu s Ústavou SR, a to odo dňa vyhlásenia nálezu Ústavného súdu SR do šiestich mesiacov, tak tieto po uplynutí tejto lehoty (6 mesiacov) strácajú svoju platnost'. Účinnost' nálezu Ústavného súdu SR je od 23.február 2019.10

Ústavný zákon č. 422/2020 Z. z. z 9. decembra 2020, ktorým sa mení a dopíña Ústava Slovenskej republiky č. 460/1992 Zb. v znení neskorších predpisov. Táto ústavná zmena (novelizácia) je v poradí dvadsiata. Národná rada Slovenskej republiky citovaným ústavným zákonom mení a doplńa Ústavu Slovenskej republiky rozsiahlejším spôsobom. Mení a dopińa sa v rámci čl. I. a čl. II. celkom okolo 25 ústavnoprávnych ustanovení, z ktorých sú niektoré čo do obsahu rozsiahlejšie a významným spôsobom sa dotkli zmeny Ústavy Slovenskej republiky. Vzhl'adom na túto ústavnú skutočnost' citovaný posledný ústavný zákon, ktorý novelizuje Ústavu SR, nerozoberáme a nehodnotíme celý, ${ }^{11}$ ale vzhl'adom na priestor pre publikovanie v článku venujeme pozornost' len tým najdôležitejším a posledným ustanoveniam. Ide teda o tieto ústavnoprávne ustanovenia:

Čl. I. okrem iného v čl. 102 ods. 1 písm. t) sa za slová „Najvyšší súd Slovenskej republiky“ vkladajú slová ,predsedu a podpredsedu Najvyššieho správneho súdu Slovenskej republiky“. V čl. 125 ods. 4 sa na konci pripája táto veta: „Ústavný súd nerozhoduje ani i súlade Ústavného zákona s ústavou.“ Týmto ústavnoprávnym ustanovením odňal vlastne zákonodarca - ústavodarca SR Ústavnému súdu právomoc rozhodovat' o súlade ústavného zákona s Ústavou. Podla nálezu Ústavného súdu z 31. mája 2017, PL. ÚS 7/2017 ZNÚS 2017, s. 264 môžeme konštatovat' že: „V podmienkach demokratického a právneho štátu nemôže žiadne rozhodnutie ústavného orgánu stát mimo ústavného prieskumu z hladiska toho či zodpovedá (neodporuje) základným ústavným princípom ako konštitutívnym hodnotám, ktoré sú nedotknutel'né a ktoré demokratický a právny

10 Bližšie pozri: Nález Ústavného súdu SR č. 40/2019 Z. z., sp. zn. PL ÚS 21/2019 z 30. januára 2019.

11 Bližšie pozri: Ústavný zákon č. 422/2020 Z. z. z 9. decembra 2020, ktorým sa mení a doplńna Ústava Slovenskej republiky č. 460/1992 Zb. v znení neskorších predpisov. 
štát rešpektuje a chráni." Na margo tohto rozhodnutia, resp. nálezu Ústavného súdu SR, významný ústavný právnik doc. JUDr. Ján Drgonec, DrSc. napísal: „V súlade s týmto pravidlom každý akt ústavného orgánu podlieha prieskumu Ústavným súdom či neporušuje Ústavu. “12 $\mathrm{S}$ citovaným názorom sa stotožňuje aj autor tohto článku.

V súvislosti so záverom novelizácie Ústavy Slovenskej republiky sa žiada poukázat' na skutočnost', že politickí reprezentanti mad’arských politických strán pri príprave návrhu Ústavy SR, ako aj pri jej novelizácií sa usilovali o zmenu obsahu Preambuly: „, My národ slovenský ..." na „My občania SR ... “. V tejto súvislosti sa žiada poukázat', že najmä pri tzv. Vel'kej novele Ústavy Slovenskej republiky okrem Preambuly ústavy boli novelou dotknuté všetky články Ústavy Slovenskej republiky.

Pri hodnotení Ústavy Slovenskej republiky a jej novelizácií sa žiada upozornit' na významnú skutočnost', že Ústava Slovenskej republiky vznikla ešte za existencie spoločného štátu Slovákov a Čechov, a to za Českej a Slovenskej Federatívnej Republiky, dňa 1. septembra 1992 (ako smeto uviedli už v predchádzajúcom texte). Táto skutočnost' podmienila to, že účinnost' Ústavy Slovenskej republiky bola realizovaná v dvoch časových termínoch, a okrem toho aj preto, aby jej obsah, resp. jej niektoré ustanovenia neboli protiústavné platnej Ústave ČSFR. Prvá účinnost' Ústavy SR bola jej vyhlásením v Zbierke zákonov (Zb.) 1. októbra 1992 a druhá - plná účinnost' bola dňom 1. januára 1993, kedy vznikla samostatná Slovenská republika, ako nástupnícky štát po zániku Českej a Slovenskej Federatívnej Republiky. Druhým nástupníckym štátom je Česká republika.

Pri poslednej (dvadsiatej) novele Ústavy Slovenskej republiky sa žiada konštatovat', že táto bola účelovo predložená, prerokovaná a prijatá (vládnou a parlamentnou väčšinou vo vtedajšej koalícií, na čele s predsedom vlády SR Igorom Matovičom), a to posledné dni v decembri 2020. Táto ústavná novela sa stala predmetom kritiky predovšetkým poslaneckou opozíciou v Národnej rade SR, a taktiež i sudcami a prokurátormi SR, teda i právnou praxou a taktiež i vedecko-právnou komunitou. Významnú kritiku predmetnej novely Ústavy SR urobil i popredný slovenský ústavný právnik, emeritný ústavný sudca a advokát Ján Drgonec, a to vo svojej publikovanej štúdii na tému: „Čo dal a vzal rok 2020 právnemu štátu na Slovensku“. Ján Drgonec túto kritiku spojil i s kritikou vládnych opatrení uskutočnených proti pandémii COVID-19, pritom poukázal, že predmetné vládne opatrenia porušujú l'udské práva a slobody našich občanov. Taktiež poukázal, že v súvislosti s pandémiou COVID-19 hlavný hygienik prijíma opatrenia, ktorými porušuje l'udské práva a slobody občanov, a ktoré sú protiústavné. ${ }^{13}$ Kritici predmetných opatrení poukazujú na to, že k prijatým opatreniam nebola žiadna odborná diskusia, a taktiež tieto neprešli odbornou oponentúrou, ako sa to uskutočnilo vo vyspelých štátoch Európskej únie.

Nadväzujúc na vyššie uvedené sa žiada poukázat' na skutočnost', na ktorú poukazuje Kamil Baraník v závere svojej vedeckej monografickej publikácií, a to že: „Vnútroštátna aplikácia medzinárodného práva je náročná téma, ktorá je neustále „v pohybe“. Aj ked' je tento proces tradične v rukách národného suveréna, zvyšujuca

12 DRGONEC, J.: Čo dal a vzal rok 2020 právnemu štátu na Slovensku. In https://www.infovojna. sk/article/video-doc-judr-jan-drgonec-drsc-obcan-mal-covid-vzal.

13 DRGONEC, J.: Čo dal a vzal rok 2020 právnemu štátu na Slovensku. In https://www.infovojna. sk/article/video-doc-judr-jan-drgonec-drsc-obcan-mal-covid-vzal. 
sa inter-novelizácia národných právnych poriadkov, neumožňuje túto sféru dlhodobo ignorovat. " ${ }^{14}$ Kamil Baraník d’alej vo svojej monografickej vedeckej publikácii poukazuje na ,trendy v rozvoji medzinárodného práva reflektovat' a kriticky analyzovat jeho vnútroštátnu aplikáciu, predovšetkým s ohl'adom na aktuálny stav v Slovenskej republike."15 Pritom ešte zdôrazňuje, že: „V úvodnej (kapitole) sa demonštrovala neustále rastúca relevancia medzinárodného práva v národných právnych poriadkoch." ${ }^{16}$ Je len samozrejmé, že to platí i pre Slovenskú republiku. V závere svojej vedeckej práce Kamil Baraník okrem iného ešte upozorn̆uje na významnú skutočnost', že: „... žiadna ústava, vrátane tej našej slovenskej, nie je dokonalým dielom a musí sa s plynutím času prehodnocovat'. A to aj napriek tomu, že každá ústava by mala reprezentovat' určité (stabilné) hodnotové ukotvenie danej spoločnosti. Slovenská ústava sa však v praxi ústavodarného orgánu prehodnocuje pomerne často, o čom za viac ako 27 rokov jej účinnosti svedči množstvo priamych noviel, nepriamych úprav, ako aj neustálych snáh o jej „,nevyhnutnú“ novelu na takmer každej schôdzi Národnej rady $S R{ }^{. " 17}$ Toto konštatovanie je pravdivé a škodí stabilite ústavnoprávneho systému, ako aj právnej istote občanov našej spoločnosti a v konečnom dôsledku nepôsobí pozitívne ani pre budovanie demokratického právneho štátu.

Prijatím Ústavy Slovenskej republiky 1. septembra 1992 a jej doterajšími novelizáciami, a taktiež ústavnými zákonmi a bežnými zákonmi prijatými Národnou radou SR v zákonodarnom procese, Slovenská republika rešpektuje medzinárodné právo a medzinárodné zmluvy, ktoré Slovenská republika ratifikuje a ktoré vyhlasuje v Zbierke zákonov SR. Pritom sa žiada poukázat’ na významnú skutočnost', že čl. 7 ods. 2 druhá a tretia veta Ústavy SR zakotvuje, že: „Právne záväzné akty Európskych spoločenstiev a Európskej únie majú prednost' pred zákonmi Slovenskej republiky. Prevzatie právne záväzných aktov, ktoré vyžadujú implementáciu, sa vykoná zákonom alebo nariadením vlády podl'a čl. 120 ods. 2." Toto citované ústavné ustanovenie zakotvuje, že: „Ak tak ustanoví zákon, vláda je oprávnená vydávat' nariadenia aj na vykonanie Európskej dohody o pridruženi uzatvorenej medzi Európskymi spoločenstvami a ich členskými štátmi na strane jednej a Slovenskou republikou na strane druhej a na vykonanie medzinárodných zmlúv podl'a čl. 7 ods. 2." Okrem citovanej implementácie, ústavné právo SR (štátoveda) umožňuje aproximáciu a recepciu medzinárodného práva a medzinárodných zmlúv.

\section{Záver}

Na záver našej štúdie sa žiada upozornit’ na skutočnost', že Ústava Slovenskej republiky ako základný zákon štátu vrátane jej dvadsiatich noviel vytvorila základné politické a ústavnoprávne predpoklady na vstup Slovenskej republiky do euroatlantických štruktúr, t. j. do NATO a Európskej únie a taktiež do mnohých medzinárodných organizácií. Taktiež okrem iného vytvorila politické a ústavnoprávne predpoklady pre

14 BARANÍK, K. Ústava na hviezdnom nebi : vztah Ústavy Slovenskej republiky k medzinárodnému právu. 1. vyd. Praha : Leges, s.r.o., 2020, s. 272.

15 Tamtiež. cit. d. s. 272.

16 Tamtiež. cit. d. s. 272.

17 Tamtiež. cit. d. s. 273. 
rozvoj demokracie a budovanie pluralitného politického a ekonomického systému, ako aj demokratického právneho štátu budovaného na princípoch trhového hospodárstva pri rešpektovaní sociálnych a ekologických aspektov, a tiež pri realizácii a zárukách ochrany l'udských práv a slobôd našich občanov. Okrem uvedeného Ústava Slovenskej republiky vytvorila i základy pre mierovú spoluprácu s demokratickými štátmi sveta. Pritom Ústava Slovenskej republiky v novelizovanom platnom znení predstavuje európsky štandard a je porovnatel'ná a ústavami najmä štátov Európskej únie. $^{18}$

\section{Literatúra:}

- BARANÍK, K. 2020. Ústava na hviezdnom nebi : vzt'ah Ústavy Slovenskej republiky k medzinárodnému právu. 1. vyd. Praha : Leges, s.r.o., 2020. $296 \mathrm{~s}$.

- ČIČ, M. 1996. Živé slová. Slovenský rozhlas : Bratislava, 1996.

- DRGONEC, J. Čo dal a vzal rok 2020 právnemu štátu na Slovensku. In : https:// www.infovojna.sk/article/video-doc-judr-jan-drgonec-drsc-obcan-mal-covid-vzal.

- FÁBRY, B. - KASINEC, R. - TURČAN, M. 2017. Teória práva. Bratislava : Wolters Kluwer 2017.

- CHOVANEC, J. 2002. Ústava SR - základný zákon štátu. Bratislava : Procom, 2002. $615 \mathrm{~s}$.

- CHOVANEC, J. - PALÚŠ, J. 2004. Lexikón ústavného práva. Bratislava: Procom, 2004. $261 \mathrm{~s}$.

- GIBA, M. 2019. Ústavné právo. Bratislava : UK, 2019.

- GIBA, M.2012: Potrebuje slovenská ústava zmenu? In: Ústava Slovenskej republiky 20 rokov v národnom a európskom pohl'ade. Lutila : Lonfinger, 2012, s.193-209.

- HOLLANDER, P. 1995. Základy všeobecné státovědy. Praha : Vyšehrad, 1995.

- HOLLANDER, P. 2012. Základy obecné státovědy. 3 vydání. Plzeň : Aleš Čeněk, 2012.

- KLÍMA, K. 2011. Státověda. 2 vydání. Plzeň : Aleš Čeněk, 2011.

- PALÚŠ, J. a kol.2016. Ústavné právo Slovenskej republiky. Košice: Fakulta verejnej správy UPJŠ, s. 58 - 70, 2016.

- POSLUCH, M. - CIBULKA, L. 2009. Štátne právo Slovenskej republiky, 3. vydanie. Šamorín : Heuréka, 2009. 341 s.

- PAVLÍČEK, V. a kol. 2015. Ústavní právo a státověda. I. díl-Obecná státověda. 2015.

- PROCHÁZKA, R. - KÁČER, M. 2013. Teória práva. 1. Vyd. Bratislava : C. H. Beck, 2013.

\section{Summary: Constitution of the Slovak Republic - Concept, Origin, Structure and Amendment}

The Constitution of the Slovak Republic as the basic law of the state, including its twenty amendments, created the basic political and constitutional preconditions for the Slovak Republic's entry into Euro-Atlantic structures (NATO and the European

18 Porovnaj: CHOVANEC, J.: Ústava Slovenskej republiky - základný zákon štátu. Bratislava: Procom, 2003, s. 14 a s. 136. 
Union) and also into many international organizations. It has also created, among other things, the political and constitutional preconditions for the development of democracy and the building of a pluralistic political and economic system, as well as a democratic rule of law based on market economy principles, while respecting social and environmental aspects. In addition to the above, the Constitution of the Slovak Republic also created the foundations for peaceful cooperation with the democratic states of the world. At the same time, the Constitution of the Slovak Republic, as amended, represents a European standard and is comparable to the constitutions of the states of the European Union in particular.

Dr. h. c. prof. JUDr. Jaroslav Chovanec, CSc. Univerzita sv. Cyrila a Metoda v Trnave

Fakulta masmediálnej komunikácie, Katedra právnych a humanitných vied Nám. J. Herdu 2 91701 Trnava

Slovenská republika sintec@stonline.sk 